\title{
Prevalence and factors associated with effective helmet use among motorcyclists in Mysuru City of Southern India
}

\author{
Naveen Kikkeri Hanumantha Setty ${ }^{1 *}$ (D), Gautham Melur Sukumar², Sumanth Mallikarjun Majgi ${ }^{3}$, \\ Akhil Dhanesh Goel' ${ }^{1}$, Prem Prakash Sharma ${ }^{1}$ and Manasa Brahmanandam Anand ${ }^{3}$
}

\begin{abstract}
Background: Helmet use reduces the risk and severity of head injury and death due to road traffic crash among motorcyclists. The protective efficacy of different types of helmets varies. Wearing firmly fastened full-face helmet termed as effective helmet use provides greatest protection. This study estimates the prevalence and factors associated with effective helmet use among motorcyclists in Mysuru, a tier II city in Southern India.

Methods: Cross-sectional road side observational study of 3499 motorcyclists (2134 motorcycle riders and 1365 pillion riders) at four traffic intersections was done followed by interview of random sample of 129 of the above riders. Effective helmet use proportion and effective helmet use per 100 person-minute of observation was calculated. Multivariate logistic regression analysis was done to identify factors associated with effective helmet use.

Results: Prevalence of effective helmet use was 28 per 100 riders and 19.5 per 100 person-minute of observation in traffic intersections. Prevalence rates of effective helmet use was higher among riders (34.5\% vs pillion riders 18.1\%), female riders (51.3\% vs male riders $26.8 \%$ ), and male pillion riders (30.5\% vs female pillion riders $13.7 \%$ ). Riders commuting for work and school and those ever stopped by the police in the past 3 months had significantly higher odds of effective helmet use.
\end{abstract}

Conclusion: Despite helmet use being compulsory by law for motorcyclists, the effective helmet use was low in Mysore. Strict enforcement and frequent checks by the police are necessary to increase the effective helmet use.

Keywords: Helmet, Motorcycle, Cross-sectional study

\section{Introduction}

Road traffic injuries are currently estimated to be the eighth leading cause of death across all age groups globally and are predicted to become the seventh leading cause of death by $2030[1,2]$. Worldwide, road traffic crashes contribute to nearly 1.35 million deaths and 50 million nonfatal injuries every year $[1,2]$. One fourth of road traffic deaths are among motorcyclists [2]. In high-income

\footnotetext{
* Correspondence: naveenkhdoc@gmail.com

'Department of Community Medicine and Family Medicine, All India Institute of Medical Sciences (AllMS), Basni phase 2, Jodhpur, Rajasthan 342005, India Full list of author information is available at the end of the article
}

countries, motorcycle deaths typically comprise about $12 \%$ of overall traffic deaths; in middle-income countries, this more than doubles to $26 \%$, and this proportion is $34 \%$ in South-East Asian Region [2]. Two-wheeler rider deaths comprise $34-71 \%$ of all accident deaths in India [3].

Motorcycles form a high proportion of vehicle fleets in many low- and middle-income countries $[1,4]$. In India, of the 253 million vehicles registered during 2017, 73.9\% are two wheelers [5].

Head injuries account for $88 \%$ of death among motorcyclists in low- and middle-income countries [4]. Wearing a helmet reduces the risk of head injuries by $69 \%$

(C) The Author(s). 2020 Open Access This article is licensed under a Creative Commons Attribution 4.0 International License, which permits use, sharing, adaptation, distribution and reproduction in any medium or format, as long as you give appropriate credit to the original author(s) and the source, provide a link to the Creative Commons licence, and indicate if changes were made. The images or other third party material in this article are included in the article's Creative Commons licence, unless indicated otherwise in a credit line to the material. If material is not included in the article's Creative Commons licence and your intended use is not permitted by statutory regulation or exceeds the permitted use, you will need to obtain permission directly from the copyright holder. To view a copy of this licence, visit http://creativecommons.org/licenses/by/4.0/ The Creative Commons Public Domain Dedication waiver (http://creativecommons.org/publicdomain/zero/1.0/) applies to the data made available in this article, unless otherwise stated in a credit line to the data. 
and possibilities of death by $42 \%$ [6]. However, a large proportion of motorcyclists suffer head injuries in road crash in spite of wearing helmets. There are different types of helmets and their effectiveness in preventing head injury varies. Head injury is more severe among those who wear non-standard helmet than those who wear standard helmet [7]. Evidence indicates that traumatic brain injury and impact during road crash decreases in standard as well as full-face helmet users [3, 8-12]. Full-face helmet provides facial protection in addition to head protection [4]. Also, risk of head and brain injury is high among motorcyclists with loosely fastened helmets compared to those with firmly fastened helmets [11]. Thus, using standard, full-face, and properly strapped helmet termed as effective helmet use is key to reducing injuries and deaths to greatest extent in motorcycle crash. Previous road side observational studies examined the prevalence and factors associated with helmet use (any helmet or proper helmet use) but none of them specifically studied use of full-face and properly strapped helmet $[9,13-15]$. With this background, we assessed prevalence and factors associated with effective helmet use among the motorcyclists in Mysuru, a tier II city in Southern India.

\section{Methods}

Mysuru is district headquarter located in the southernmost part of Karnataka. The Mysuru district lies between $11^{\circ} 44^{\prime}$ to $12^{\circ} 37^{\prime}$ North latitude and $75^{\circ} 57^{\prime}$ to $77^{\circ} 12^{\prime}$ East longitude [16]. It is the third most populous district in the state of Karnataka, with population of around 30 lakhs. Mysuru City population is over 9 lakhs and stands 2nd in terms of urban population in Karnataka $[17,18]$. Density of population is $476 / \mathrm{km}^{2}$ which is much lower compared to Bengaluru, capital city of Karnataka $\left(4381 / \mathrm{km}^{2}\right)$ [18]. It is classified under tier II city or category Y based on the population density by government of India. The cost of living is less compared to other major metropolitan tier 1 (Category $\mathrm{X}$ ) cities in India [19].

Mysuru City has radial and gridiron pattern road network with arterial roads originating from the city center. Mysuru Palace, a renowned tourist attraction, is the focal point of origin of all arterial roads running radially to outer areas of the city. The road network of the city also includes three ring roads viz. outer ring road, intermediate ring road, and inner ring road. The three ring roads not only collect traffic from other roads but also act as by-pass roads at their respective locations in order to avoid congestion especially at the core of the city. Apart from these, national highways and state highways pass through Mysuru connecting it to other cities in Karnataka, Tamilnadu, and Kerala [20]. Mysuru has recorded $130 \%$ growth in the vehicles registered between
2010 and 2015. Motorcycles constitute around $80 \%$ of the total vehicles registered [21].

The present cross-sectional study involved observation of motorcyclists and road side interviews of a random sample of the observed motorcyclists in four traffic intersections in the city of Mysuru, Karnataka, India. The four sites were identified in consultation with the traffic police and selected based on highest average traffic volume, safety, and feasibility of location for observation/ interview.

Date collection was done by three trained independent observers for a period of one week at each of the selected sites during August 2016. The three observers took position on the side of the road close to a traffic signal. The first and second observers recorded observations for motorcycle rider and pillion rider respectively, by observing all motorized two-wheelers moving in one direction, continuously for 90 minutes from 4:30 PM to 6:00 PM (peak hour). Any helmet use and helmet usage pattern (use of standard or non-standard helmet, fullface helmet or open-face and whether the helmet was firmly fastened or not) and gender was noted. If more than one motorcycle was passing at the same time, data was captured for the motorcycle that is closest to the side of the road. Validated data collection formats developed by Wadhwaniya et al. [13] were adapted for recording the observations.

The third observer randomly stopped the motorcycle that is closest to the side of the road passing away from the first two observers. The purpose of the study was explained and motor cycle riders were included in the study after obtaining the informed verbal consent. A validated questionnaire developed by Wadhwaniya et al. was adapted for the interview [13]. The investigator administered a set of questions consisting of age and educational status of the rider, ownership of the motorcycle, factors important while purchasing the helmet, cost of the helmet, place of purchase of the helmet, purpose of the trip, do you always wear helmet, reasons for wearing or not wearing the helmet always and in the past 3 months have they ever been stopped by the police to check helmet use. Data collectors were trained both in the class room and in the field. Based on the review of published articles and WHO report the helmet usage pattern was defined as follows [4, 7, 11, 22, 23]: standard helmet, which is either a full-face or open-face helmet. Non-standard helmet, which refers to helmets that were designed for another purpose (horse riding helmet, construction helmet), half-coverage helmet, which is not open-face or full-face helmet [22, 23]. Proper helmet use constitutes wearing standard helmet (open-/fullface) and firmly strapped. Effective helmet use constitutes wearing standard, full-face, and firmly strapped helmet [11]. 
The project proposal was submitted and approval was obtained from the Institution Ethics Review Board (IERB) of Mysore Medical College and Research Institute (MMC and RI), Mysuru in the state of Karnataka, India. Permission was also obtained from Mysuru City traffic police.

Data was entered into Microsoft excel sheet and analysed using SPSS version 23.0. Over a period of 4 weeks, 2134 motorcycle riders and 1365 pillion riders were observed. Among the motorcycle riders observed, 129 were interviewed. Prevalence of any helmet use, standard, fullface, proper, and effective helmet use per 100 motorcyclists was calculated. Specific prevalence rates provided for rider, pillion rider, male, and female. Person-minutes of observation was calculated as number of observers $x$ minutes of observation $x$ number of days of observation. Single observer observed the motorcycle riders for 90 min every day for 28 days giving rise to 2520 person minutes of observation. This served as denominator for calculating the helmet use for riders and pillion riders. While calculating the same indicators for total motorcyclists (riders + pillion riders), the denominator used was 5040 person minutes of observation ( 2 observers $\times 90$ min $\times 28$ days). Similarly, violation of helmet use was expressed per 100 person-minutes of observation. $Z$ test for difference between two proportions and chi-square test for categorical variables were calculated. Categorical variables which were found significant on chi-square test at $20 \%$ level (age, education status, purpose of the trip and in the past 3 months have you ever been stopped by police to check helmet use?) were included in the multivariate analysis. Multivariate analysis was done using stepwise forward (likelihood ratio) binary logistic regression method with level of significance set at 0.05 .

\section{Results}

\section{Prevalence and patterns of helmet use}

Among the total motorcyclists $(n=3499)$, only $28.1 \%$ were effective helmet users. Effective helmet use was significantly higher among motorcycle riders in comparison to pillion riders $(p<0.001)$. Also, significantly higher proportion of riders were proper $(p<0.001)$, full-face $(p$ $<0.001)$, standard $(p<0.001)$, and any helmet $(p<$ 0.001 ) users as compared to the pillion riders (Table 1 and Fig. 1).

The effective helmet use among all the motorcyclists was 19.5 per 100 person-minutes of observation and among riders and pillion riders it was 29.2 and 9.8 per 100 person-minutes of observation respectively (Table 2).

Violations of helmet use per 100 person-minutes of observation were also calculated. Among all motorcyclists, non-effective helmet use was $16.7 / 100$ personminutes of observation and it was 21.5 and 12.0 per 100
Table 1 Distribution of riders and pillion riders based on helmet use

\begin{tabular}{|c|c|c|c|}
\hline $\begin{array}{l}\text { Riders } \\
(\boldsymbol{n}=2134)\end{array}$ & $\begin{array}{l}\text { Pillion riders } \\
(\boldsymbol{n}=1365)\end{array}$ & $\begin{array}{l}\text { Total } \\
(\boldsymbol{n}=3499)\end{array}$ & $\boldsymbol{p}$ value ${ }^{\mathrm{a}}$ \\
\hline No. $(\%)$ & (\%) & & \\
\hline
\end{tabular}

Use per 100 riders or pillion riders observed

$\begin{array}{llllllll}\text { Helmet use } & 1961 & (91.9) & 915 & (67.0) & 2876 & (82.2) & <0.001 \\ \text { Standard helmet use } & 1278 & (59.9) & 549 & (40.2) & 1827 & (52.2) & <0.001 \\ \text { Full-face helmet use } & 1106 & (51.8) & 423 & (31.0) & 1529 & (43.7) & <0.001 \\ \text { Proper helmet use } & 880 & (41.2) & 354 & (25.9) & 1234 & (35.3) & <0.001 \\ \text { Effective helmet use } & 737 & (34.5) & 247 & (18.1) & 984 & (28.1) & <0.001\end{array}$

Proper helmet use $=$ those using standard helmet and firmly strapped

Effective helmet use $=$ those using standard, full-face helmet and

firmly strapped

${ }^{\mathrm{a}} Z$ test for difference between proportions

person-minutes of observation among riders and pillion riders respectively (Fig. 2).

Majority of the motorcycle riders were males $(n=$ $1462,68.5 \%)$, whereas majority of pillion riders were females $(n=1008,73.9 \%)$. All female riders were wearing any helmet while $88.2 \%$ male riders were found wearing any helmet. Significantly higher proportion of female riders were effective helmet $(51.3 \%)$ users in contrast to male riders $(26.8 \%)(p<0.001)$. Among the pillion riders, $70.5 \%$ of female and $57.1 \%$ of males were wearing any helmet $(p<0.001)$. However, effective helmet use was significantly higher among male pillion riders $(p<$ 0.001). On comparing the helmet usage pattern of female riders and pillion riders, significantly higher proportion of female motorcycle riders were effective helmet users as compared to female pillion riders $(p<$ $0.001)$. On the other hand, male motorcycle riders and pillion riders did not show such significant difference in their helmet use (Table 3).

\section{Characteristics of motorcycle riders interviewed}

Among the 129 motorcycle riders interviewed, 63 $(48.8 \%)$ were aged below 30 years, 43 (33.3\%) were educated up to 12th or below, 65 (50.4\%) were studying or completed bachelor's degree, and only 21 (16.3\%) were studying or completed post-graduation; 76 (58.9\%) were riding motorcycle of engine capacity above $100 \mathrm{CC}$, majority owned the motorcycle ( $n=$ $127,98.4 \%)$ and $84(65.1 \%)$ were traveling to/from work or school (Table 4). While purchasing the helmet motorcycle riders placed more importance on quality $(n=97,75.2 \%)$ and certification $(n=52$, $40.3 \%)$ over brand $(n=27,20.9 \%)$, style/look $(n=22$, $17.1 \%)$, and comfort $(n=20,15.5 \%)$. Of the 123 riders wearing helmet, certification sticker was observed in $75(58.1 \%)$ helmet, of which $73(97.3 \%)$ were authentic and 70 (56.9\%) were wearing the helmet which cost rupees 500 or less (Table 4). Majority 


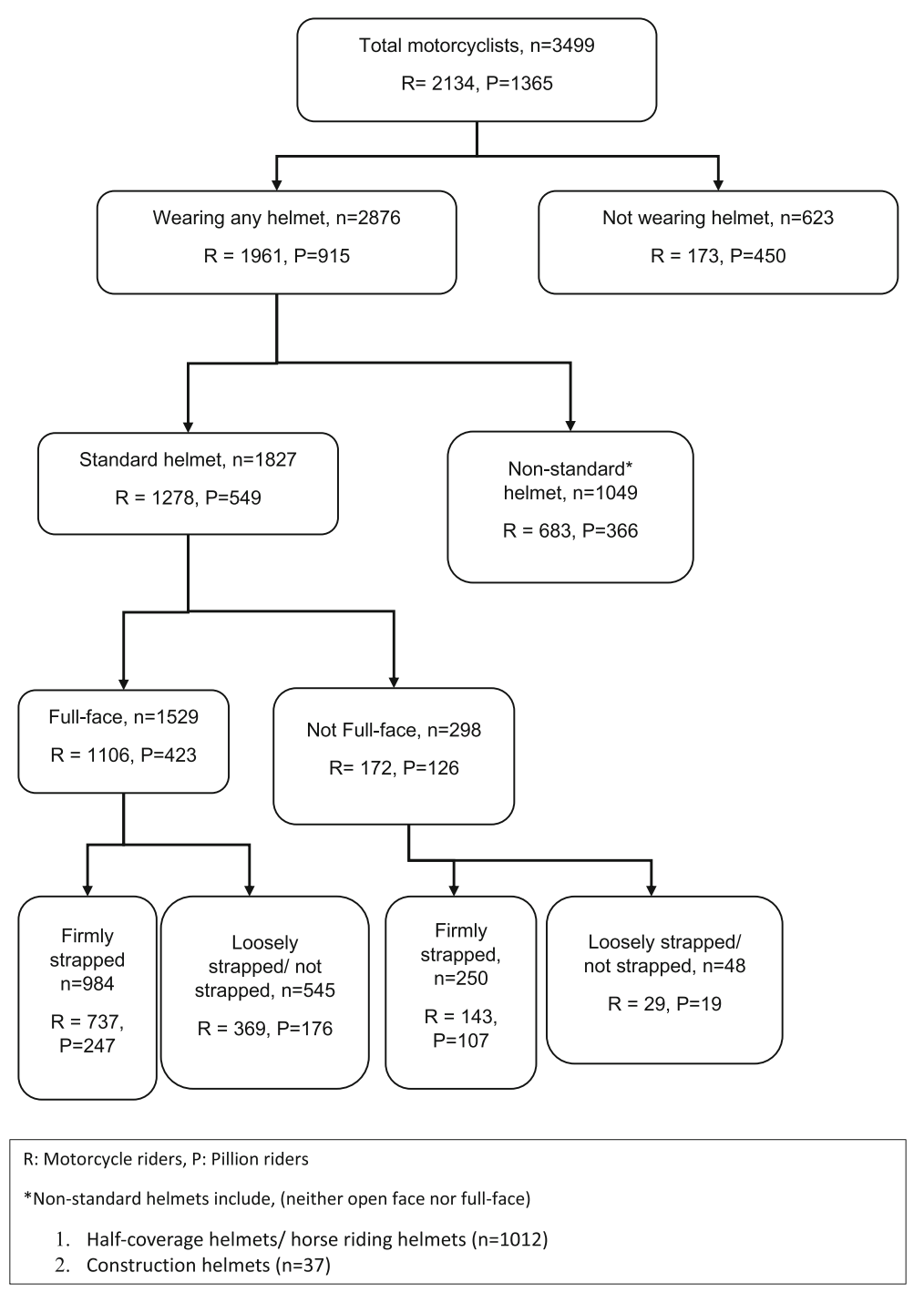

Fig. 1 Helmet usage pattern among motorcyclists

Table 2 Helmet use per 100 person-minutes of observation

\begin{tabular}{llll}
\hline & Riders $^{\mathrm{a}}$ & ${\text { Pillion } \text { riders }^{\mathrm{a}}}$ & Total $^{\mathrm{b}}$ \\
\hline Helmet use & 77.8 & 36.3 & 57.1 \\
Standard helmet use & 50.7 & 21.8 & 36.3 \\
Full-face helmet use & 43.9 & 16.8 & 30.3 \\
Proper helmet use & 34.9 & 14.0 & 24.5 \\
Effective helmet use & 29.2 & 9.8 & 19.5
\end{tabular}

Use per 100 person-minutes of observation $=($ Number of users $\times 100) / D$ $D$ (Denominator) $=$ Number of data collectors $\times$ number of days $\times$ (number of minutes/day)

${ }^{\mathrm{a}}$ For Riders/Pillion riders $=(1 \times 28 \times 90)=2520$ person-minutes of observation

${ }^{\mathrm{b}}$ For total motorcyclists $($ riders + pillion $)=(2 \times 28 \times 90)=5040$ personminutes of observation

Example for helmet use (riders) $=1961 \times 100 / 2520=77.8$ helmet users per 100 person-minutes of observation purchased their helmet from a helmet-specific shop $(n=88,71.6 \%)$, few purchased from shopping mall $(n$ $=22,17.9 \%)$ and street seller $(n=10,8.1 \%)$, and rest borrowed helmet from someone $(n=3,2.4 \%)$.

Out of the 129 motorcycle riders, 119 (92.2\%) said that they always wear a helmet. The most common reason for wearing the helmet always was "it can save my life" ( $n=103,86.6 \%)$. Each of the rest, $8(6.7 \%)$ said that they always wear helmet because police can fine them or it is required by the law. Among 10 (7.8\%) respondents who answered they do not wear the helmet always reported that most often they forget to wear $(n=8,80.0 \%)$ or they consider themselves to be a highly skilled driver ( $n$ $=1,10.0 \%)$ or it is uncomfortable to wear the helmet $(n$ $=1,10.0 \%)$. Only 26 (20.2\%) motorcycle riders were ever stopped by the police to check helmet use in the past 3 months (Table 4). 


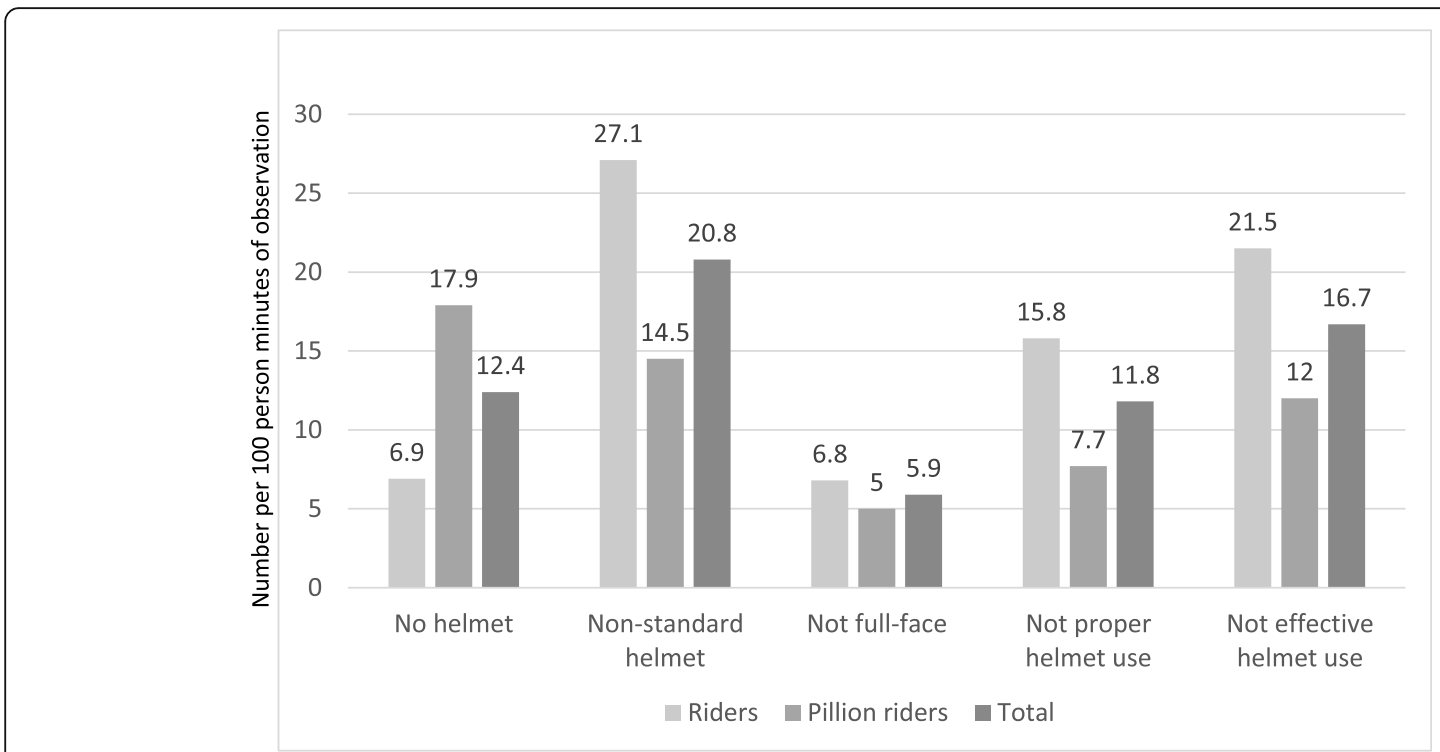

Fig. 2 Violations of helmet use per 100 person-minutes of observation

\section{Factors affecting effective helmet use}

Of the 129 motorcycle riders, 31 (24.0\%) were effective helmet users. On univariate analysis age ( $p=$ $0.016)$, purpose of the trip $(p=0.003)$, education status ( $p=0.157)$, and being ever stopped by the police in the past 3 months $(p=0.158)$ were factors affecting effective helmet use at $p<0.20$ level (Table 4).

The explanatory variables which were found significant on univariate analysis at $20 \%$ level were included in multivariate analysis. After controlling for other covariates motorcycle riders who were travelling to/from the work or school had 8.3 odds (95\% CI 2.3-30.5) of wearing the helmet effectively compared to those travelling to/from leisure activities or travelling for pleasure. Those riders who were ever stopped by the police to check helmet use in the past 3 months had 4.4 odds (95\% CI 1.4-14.1) of effective helmet use as compared to those who were not stopped so (Table 5).

\section{Discussion}

The effective helmet use in the present study among the motorcyclists (both rider and pillion rider) was $28.1 \%$. We assessed effective helmet use as evidence indicates that chin area would see high impact in event of road crash and full-face helmet provides highest protection compared to open-/half-face helmet $[8,10,11]$. Effectiveness is better when the helmet strap is properly fastened [11]. Any deviation from this leads to lower protection and increased risk and severity of head injury [11]. Earlier road side observational studies assessed any helmet, standard, full-face, and proper helmet use [12$14,22-24]$. None of the studies specifically measured the prevalence of effective helmet use (standard, full-face and firmly fastened). However, in a hospital-based casecontrol study on motorcycle crash injury victims in Taiwan the use of full-face, firmly fastened helmet was found to be $8.7 \%$ [11].

The use of any helmet was reported to be nearly $90 \%$ and above after the introduction of helmet law in

Table 3 Distribution of riders and pillion riders based on helmet use and sex

\begin{tabular}{|c|c|c|c|c|c|c|c|c|c|c|c|c|}
\hline & \multicolumn{4}{|c|}{ Riders $(\boldsymbol{N}=2134)$} & \multicolumn{4}{|c|}{ Pillion riders $(\boldsymbol{N}=1365)$} & \multicolumn{4}{|l|}{$\boldsymbol{p}$ value $^{a}$} \\
\hline & \multicolumn{2}{|c|}{ Male (a) $(\boldsymbol{n}=1462)$} & \multicolumn{2}{|c|}{ Female (b) $(\boldsymbol{n}=672)$} & \multicolumn{2}{|c|}{ Male (c) $(\boldsymbol{n}=357)$} & \multicolumn{2}{|c|}{ Female (d) $(\boldsymbol{n}=1008)$} & \multirow[t]{2}{*}{$a$ vs b } & \multirow[t]{2}{*}{$c$ vs d } & \multirow[t]{2}{*}{ a vs C } & \multirow[t]{2}{*}{$b$ vs d } \\
\hline & No. & (\%) & No. & (\%) & No. & (\%) & No. & (\%) & & & & \\
\hline Helmet use & 1289 & $(88.2)$ & 672 & $(100.0)$ & 204 & (57.1) & 711 & $(70.5)$ & $<0.001$ & $<0.001$ & $<0.001$ & $<0.001$ \\
\hline Standard helmet use & 765 & $(52.3)$ & 513 & $(76.3)$ & 177 & $(49.6)$ & 372 & (36.9) & $<0.001$ & $<0.001$ & 0.352 & $<0.001$ \\
\hline Full-face helmet use & 720 & $(49.3)$ & 386 & $(57.4)$ & 167 & $(46.8)$ & 256 & $(25.4)$ & $<0.001$ & $<0.001$ & 0.401 & $<0.001$ \\
\hline Proper helmet use & 418 & $(28.6)$ & 462 & $(68.8)$ & 115 & $(32.2)$ & 239 & $(23.7)$ & $<0.001$ & 0.002 & 0.177 & $<0.001$ \\
\hline Effective helmet use & 392 & $(26.8)$ & 345 & (51.3) & 109 & (30.5) & 138 & (13.7) & $<0.001$ & $<0.001$ & 0.159 & $<0.001$ \\
\hline
\end{tabular}

${ }^{\mathrm{a}} Z$ test for difference between two proportions, vs versus 
Table 4 Characteristics of motorcycle riders interviewed $(n=129)$ and effective helmet use

\begin{tabular}{|c|c|c|c|c|c|c|c|}
\hline & \multicolumn{6}{|c|}{ Effective helmet use (riders) } & \multirow{3}{*}{$\boldsymbol{p}$ value } \\
\hline & \multicolumn{2}{|c|}{ Yes $(\boldsymbol{n}=31)$} & \multicolumn{2}{|c|}{ No $(\boldsymbol{n}=98)$} & \multicolumn{2}{|c|}{ Total } & \\
\hline & No. & $(\%)$ & No. & (\%) & No. & $(\%)$ & \\
\hline \multicolumn{8}{|l|}{ Age $(n=129)$} \\
\hline$<30$ years & 21 & $(33.3)$ & 42 & $(66.7)$ & 63 & $(100.0)$ & 0.016 \\
\hline$\geq 30$ years & 10 & $(15.2)$ & 56 & $(84.8)$ & 66 & $(100.0)$ & \\
\hline \multicolumn{8}{|l|}{ Education status ( $n=129)$} \\
\hline$\leq 12$ th & 7 & $(16.3)$ & 36 & $(83.7)$ & 43 & $(100.0)$ & 0.157 \\
\hline $\begin{array}{l}\text { Bachelor's degree } \\
\text { (Studying/completed) }\end{array}$ & 16 & $(24.6)$ & 49 & $(75.4)$ & 65 & $(100.0)$ & \\
\hline $\begin{array}{l}\text { Post-graduation } \\
\text { (Studying/completed) }\end{array}$ & 8 & $(38.1)$ & 13 & $(61.9)$ & 21 & $(100.0)$ & \\
\hline \multicolumn{8}{|l|}{ Cost of helmet $(n=123)$} \\
\hline$\leq 500$ INR $(\leq$ US $\$ 7.5)$ & 17 & $(24.3)$ & 53 & $(75.7)$ & 70 & $(100.0)$ & 0.788 \\
\hline$>500$ INR (> US \$7.5) & 14 & $(26.4)$ & 39 & (73.6) & 53 & $(100.0)$ & \\
\hline \multicolumn{8}{|c|}{ Engine capacity (Cc) ( $n=129)$} \\
\hline$\leq 100$ & 13 & $(24.5)$ & 40 & $(75.5)$ & 53 & $(100.0)$ & 0.912 \\
\hline$>100$ & 18 & $(23.7)$ & 58 & $(76.3)$ & 76 & $(100.0)$ & \\
\hline \multicolumn{8}{|c|}{ Purpose of the trip $(n=129)$} \\
\hline $\begin{array}{l}\text { Travel to/from } \\
\text { School/work }\end{array}$ & 27 & $(32.1)$ & 57 & $(67.9)$ & 84 & $(100.0)$ & 0.003 \\
\hline $\begin{array}{l}\text { Travel to/from leisure } \\
\text { Activities/pleasure }\end{array}$ & 4 & (8.9) & 41 & $(91.1)$ & 45 & $(100.0)$ & \\
\hline \multicolumn{8}{|c|}{ Do you always wear a helmet? $(n=129)$} \\
\hline Yes & 31 & $(26.1)$ & 88 & $(73.9)$ & 119 & $(100.0)$ & - \\
\hline No & 0 & $(0.0)$ & 10 & $(100.0)$ & 10 & $(100.0)$ & \\
\hline \multicolumn{8}{|c|}{ In the past 3 months, have you ever been stopped by police to check helmet use? ( $n=129)$} \\
\hline Yes & 9 & (34.6) & 17 & $(65.4)$ & 26 & $(100.0)$ & 0.158 \\
\hline No & 22 & (21.4) & 81 & (78.6) & 103 & $(100.0)$ & \\
\hline
\end{tabular}

INR Indian Rupees

Figures in parenthesis are row wise percentages

${ }^{a}$ Chi-square

California, Taiwan, and Italy [12, 25, 26]. Another study reported $88 \%$ helmet use in the states with universal helmet law [27]. On the similar lines, there is a positive tendency of wearing any helmets as seen in $82 \%$ of the motorcyclists observed in this study. However, the use of standard (52.2\%), full-face (43.7\%), and proper helmet (35.3\%) was low. Nevertheless, the use of any helmet, standard, and proper helmet was higher compared to other studies done in India and abroad [11, 14, 22, 23, 28, 29]. With strict enforcement of helmet law, there

Table 5 Binary logistic regression analysis-forward step wise [LR] method ${ }^{a}$

\begin{tabular}{|c|c|c|c|}
\hline & Unadjusted OR [95\% Cl] & Adjusted OR [95\%Cl] & $\boldsymbol{p}$ value \\
\hline \multicolumn{4}{|l|}{ Purpose of the trip } \\
\hline $\begin{array}{l}\text { Travel to/from } \\
\text { School/work }\end{array}$ & $4.9[1.6$ to 14.9$]$ & $8.3[2.3$ to 30.5$]$ & 0.001 \\
\hline $\begin{array}{l}\text { Travel to/from leisure } \\
\text { Activities/pleasure }\end{array}$ & Reference & Reference & \\
\hline \multicolumn{4}{|c|}{ In the past 3 months, have you ever been stopped by police to check helmet use? } \\
\hline Yes & $1.9[0.8$ to 4.9$]$ & $4.4[1.4$ to 14.1$]$ & 0.013 \\
\hline No & Reference & Reference & \\
\hline
\end{tabular}

${ }^{\mathrm{a}} \mathrm{Age}$ and education status were the other variables included in the regression analysis 
may be increase in the helmet use; however, large number of motorcyclists may wear non-standard helmet or wear them improperly [28].

The low prevalence of effective helmet use may be due to lack of awareness of protective efficacy of different helmet types and proper fastening of strap even though motorcyclists were aware of life saving potential of helmets [13]. There are motorcyclists who habitually do not strap and another set who wear helmets only to please the traffic police and avoid the penalty. The latter group tend to remove the helmet when they move out of eyes of traffic police [30, 31].

Over $50 \%$ of participants spent INR 500 (US \$7.5) or less on helmet. Higher costs of standard and full-face helmets [23] prevents their use, though motorcyclists place importance on quality, certification [13], and brand of helmet while purchasing. People often tend to forget wearing helmet; however, those who are engaged in routine activity like commuting to work or school are more likely to wear one $[14,23]$ and wear it effectively. In this study, $20.2 \%$ of the riders were ever stopped by the police to check helmet use in the past 3 months which is nearly ten times higher compared to a study done in Hyderabad, India [13]. Infrequent check for helmet use by traffic police and slackness in the enforcement of helmet law results in low prevalence of helmet use [32] and also effective helmet use. Discomfort [33] and over confidence or unrealistic optimism [34] of motorcyclists are other factors that can affect effective helmet use. However, unrealistic optimism was not examined in this study. Few studies have reported age and education of motorcyclists as significant factors for proper helmet use $[13,14,23]$. However, such association was not found in the present study.

Findings of this study indicate effective helmet use as well as other helmet use pattern was significantly lower among pillion riders. Evidence indicates lower prevalence of helmet as well as proper helmet use among pillion riders $[3,13,14]$. But the reasons for low prevalence among them was not explored in this study.

The effective helmet use was significantly higher among female motorcycle riders. Studies report better compliance among females [14, 23, 35]. However, as pillion riders, it was significantly lower among them similar to a study from Delhi [36]. There was a significant change in the helmet use behavior of female motorcyclists as riders and pillion riders whereas male motorcyclists were consistent in their behavior whether as riders or pillion riders. Even though level of risk perception is same for both sex, women were more concerned about risk of road crash [37] which justifies higher compliance. Such gender differences in helmet use needs to be further explored in future research studies.
Novel method was tried to estimate helmet use considering human effort in denominator as number of observers and the time spent by each of them, similar to indicator assessing mosquito density per man hour of catch used in mosquito surveys [38]. Estimating helmet use per person-minutes of observation can be considered as standardized indicator for such road side observation studies. It seems more meaningful when used to compare the helmet use rates across different time periods and geographical locations. With increase in helmet use, it can be used to estimate violations of helmet use. Further, various violations like seat belt and helmet violations and mobile phone use while driving can be combined and compared as density of traffic violations per 100 person-minutes/hours of observation.

Target 7 related to SDGs on road safety aims to increase proportion of motorcycle riders correctly using properly fastened standard helmets close to $100 \%$ by 2030 [1]. The enforcement level of motorcycle helmet law is 4 out of 10 points for India as per the Global status report on road safety 2018 [1]. Multipronged approach is needed to reach the target. At the government level as positive note Indian Motor vehicles act was amended in August 2019, increasing fine to 1000 rupees and disqualifying licence for a period of 3 months to those violating the rules [39]. Strict and universal enforcement with emphasis on effective helmet use, stringent regulations prohibiting manufacture, and sale of non-standard helmets and government subsidies or social marketing initiatives for standard and full-face helmets are needed. Research into development of comfortable helmets to suit local weather conditions and cost reduction and quality control by the companies. Alarm systems in motorcycles and helmets to remind wearing helmets and fastening strap respectively, similar to seat belt alarm in four wheelers should be developed. To implement innovative behavior change communication strategies to public on safety potential of effective helmet use on mission mode, with special focus on pillion riders who account for $4.8-33 \%$ of two-wheeler deaths [3] and frequent monitoring by the police. Finally, addressing gender discrimination through the existing women empowerment strategies and unrealistic optimism of motorcyclists emphasizing everyone on motorcycle are at risk of head injury and death may increase effective helmet use in future.

The study is not without limitations. Observations could not be recorded for the entire day and study may not be representative of all traffic intersections in Mysuru or other cities but may approximate helmet usage pattern during evening peak traffic flow as the observation period was nearly a month. Classification of standard helmet was based solely on structure of helmets as certification sticker could not be checked for all 
the helmets observed. This study was done near traffic intersections which is usually monitored by the traffic police. Hence, it can be overestimate of effective helmet use. The effective helmet use might be much lower in other areas which are not so monitored. Element of social desirability bias in self-reporting of helmet use cannot be ruled out. The road side interview was conducted only for motorcycle riders. Interviewing pillion riders may provide new insights into the factors associated with helmet use or non-use among them.

\section{Conclusion}

Our study indicates that effective helmet use in the Mysuru, a tier II city of southern India is very low and much lower among pillion riders. Effective helmet use was lower among male riders compared to female riders. However, this was reverse for pillion riders. Purpose of the trip and monitoring by the police are factors associated with effective helmet use. Behavior change communication strategies to be implemented addressing motorcyclists emphasizing on the uncertainties on the road. Hence, irrespective of purpose and distance travelled, every one taking out vehicle from home should wear full-face properly fastened helmet for maximum protection. It is also recommended to strengthen enforcement, increase accessibility and affordability of lowcost, high-quality, and comfortable standard full-face helmets to enhance effective helmet use in India.

\section{Acknowledgements \\ Dr. Shivam Gupta, Associate Scientist, Department of International health, Johns Hopkins Bloomberg School of Public Health, Baltimore MD 21205, USA for permission to use the questionnaire and guidance and support; Mysuru City traffic police for permission, support, and cooperation to conduct the study; all the motorcyclists who consented to participate in the study; and Dr. Swathi. G and Dr. Varun C.R. former interns at Mysore Medical College and Research Institute, Mysuru, Karnataka, India, for assisting in data collection.}

\section{Authors' contributions}

$\mathrm{NKH}, \mathrm{GMS}, \mathrm{SMM}$, and MBA conceptualized and designed the study. NKH, SMM, and MBA collected the data. NKH and MBA entered the data. NKH GMS, SMM, ADG, and SPP carried out statistical analyses and interpreted the data. NKH and ADG written the first draft. GMS, SMM, ADG, and SPP critically reviewed the draft for intellectual content and revised the manuscript. All the authors reviewed and approved the final draft.

\section{Funding}

Dr. Manasa B Anand (MBA) was awarded Indian Council of Medical Research (ICMR)-Short Term Studentship and received scholarship of INR 10,000/-. ICMR grants such studentship awards annually to motivate and promote research among medical students. ICMR-STS ID: 2016-00277. No other funding from any source was received for the study.

\section{Availability of data and materials}

The datasets during and/or analyzed during the current study available from the corresponding author on reasonable request.

\section{Ethics approval and consent to participate}

Institutional Ethics committee of Mysore Medical College and Research Institute, Mysuru, Karnataka, India, approved the study (letter dated: 23 July 2016). Informed verbal consent was obtained.
Consent for publication

Not applicable

\section{Competing interests}

The authors declare that they have no competing interests.

\section{Author details}

'Department of Community Medicine and Family Medicine, All India Institute of Medical Sciences (AlIMS), Basni phase 2, Jodhpur, Rajasthan 342005, India. ${ }^{2}$ Department of Epidemiology, Centre for Public Health, National Institute of Mental Health \& Neuro Sciences (NIMHANS), Bengaluru, Karnataka, India. ${ }^{3}$ Mysore Medical College and Research Institute (MMCRI), Mysore, Karnataka, India.

Received: 27 May 2020 Accepted: 24 August 2020

Published online: 04 September 2020

\section{References}

1. Global status report on road safety 2018. Geneva: World Health Organization 2018. https://www.who.int/publications-detail/global-statusreport-on-road-safety-2018. (Accessed 5 Apr 2020).

2. Global status report on road safety 2015. Geneva: World Health Organization 2015. www.who.int/violence_injury_prevention/road_safety_ status/2015/en/. (Accessed 6 Apr 2020).

3. Gururaj $\mathrm{G}$, Gautham MS. Advancing road safety in India-implementation is the key. Bengaluru: National Institute of Mental Health \& Neuro Sciences; 2017.

4. Helmets: a road safety manual for decision-makers and practitioners. Geneva: World Health Organization 2006. https:/www.who.int/publicationsdetail/helmets-a-road-safety-manual-for-decision-makers-and-practitioners. (Accessed 6 Apr 2020)

5. Road Transport Year Book (2016-17). New Delhi: transport research wing, Ministry of Road Transport and Highways. Govt. of India https://morth.nic.in/ sites/default/files/Road\%20Transport\%20Year\%20Book\%202016-17.pdf. (Accessed 6 Apr 2020).

6. Liu $B C$, Ivers $R$, Norton $R$, et al. Helmets for preventing injury in motorcycle riders. Cochrane Database Syst Rev. 2008:CD004333. https://doi.org/10.1002/ 14651858.CD004333.pub3.

7. Peek-Asa C, McArthur DL, Kraus JF. The prevalence of non-standard helmet use and head injuries among motorcycle riders. Accid Anal Prev. 1999;31: 229-33. https://doi.org/10.1016/s0001-4575(98)00071-2.

8. Richter $M$, Otte $D$, Lehmann $U$, et al. Head injury mechanisms in helmetprotected motorcyclists: prospective multicenter study. J Trauma. 2001;51: 949-58. https://doi.org/10.1097/00005373-200111000-00021.

9. Lam C, Wiratama BS, Chang W-H, et al. Effect of motorcycle helmet types on head injuries: evidence from eight level-I trauma centres in Taiwan. BMC Public Health. 2020:20:78. https://doi.org/10.1186/s12889-020-8191-1.

10. Otte D, Felton G. Distribution of impact locations on motorcycle helmets. In: Hough DL. Proficient Motorcycling: The Ultimate Guide to Riding Well. Irvine, California: BowTie Press 2000. https://epdf.pub/proficientmotorcycling-the-ultimate-guide-to-riding-well.html. (Accessed 4 Apr 2020).

11. Yu W-Y, Chen C-Y, Chiu W-T, et al. Effectiveness of different types of motorcycle helmets and effects of their improper use on head injuries. Int $J$ Epidemiol. 2011:40:794-803. https://doi.org/10.1093/ije/dyr040.

12. Chiu WT, Kuo CY, Hung CC, et al. The effect of the Taiwan motorcycle helmet use law on head injuries. Am J Public Health. 2000;90:793-6.

13. Wadhwaniya S, Gupta S, Tetali S, et al. The validity of self-reported helmet use among motorcyclists in India. WHO South-East Asia J Public Health. 2015;4:38-44. https://doi.org/10.4103/2224-3151.206619.

14. Wadhwaniya S, Gupta S, Mitra S, et al. A comparison of observed and selfreported helmet use and associated factors among motorcyclists in Hyderabad city, India. Public Health. 2017;144S:S62-9. https://doi.org/10. 1016/j.puhe.2016.11.025

15. Mathur AK, Gupta S, Bandhu A. A Baseline Study on Pattern of Helmet Use in the State of Rajasthan, India. J Health Manag. 2017;19:417-34. https://doi. org/10.1177/0972063417717894.

16. Census of India 2011, Karnataka. District Census Handbook: Mysore. Village and town directory. Bengaluru: Directorate of Census Operations, Karnataka. Ministry of Home affairs 2011. https://censusindia.gov.in/2011census/dchb/2 923_PART_A_DCHB_MYSORE.pdf. Accessed 4 Aug 2020. 
17. Census of India 2011, Karnataka. District Census Handbook: Mysore. Village and town wise Primary Census Abstract (PCA). Bengaluru: Directorate of Census Operations, Karnataka. Ministry of Home affairs https://censusindia. gov.in/2011census/dchb/2923_PART_B_DCHB_MYSORE.pdf. Accessed 4 Aug 2020.

18. Mysore City Population Census 2011-2020 | Karnataka. https://www.census2 011.co.in/census/city/452-mysore.html (Accessed 4 Aug 2020).

19. Classification of Indian Cities. MedPort Int. 2019.https://medport.in/ classification-of-indian-cities/ (Accessed 4 Aug 2020).

20. Welcome to the Official Website of MYSORE URBAN DEVELOPMENT AUTHORITY. http://mudamysore.gov.in/Planning.htm (Accessed 4 Aug 2020).

21. Azis Kemal F, Gudasalahalli Venkatareddy V, S N. Urban transport and automobile air pollution in Mysuru, India. Hassan: 2018. 8. https://www. researchgate.net/publication/327177236_URBAN_TRANSPORT_AND_ AUTOMOBILE_AIR_POLLUTION_IN_MYSURU_INDIA. Accessed 4 Aug 2020.

22. Buckley L, Bingham CR, Flannagan CA, et al. Observation of motorcycle helmet use rates in Michigan after partial repeal of the universal motorcycle helmet law. Accid Anal Prev. 2016;95:178-86. https://doi.org/10.1016/j.aap. 2016.07.009.

23. Ackaah W, Afukaar F, Agyemang W, et al. The use of non-standard motorcycle helmets in low- and middle-income countries: A multicentre study. Inj Prev. 2013;19:158-63. https://doi.org/10.1136/injuryprev-2012040348

24. Hung DV, Stevenson MR, Ivers RQ. Prevalence of helmet use among motorcycle riders in Vietnam. Inj Prev. 2006;12:409-13. https://doi.org/10. 1136/ip.2006.012724.

25. Servadei F, Begliomini C, Gardini E, et al. Effect of Italy's motorcycle helmet law on traumatic brain injuries. Inj Prev. 2003;9:257-60. https://doi.org/10. 1136/ip.9.3.257.

26. Kraus JF, Peek C, Williams A. Compliance with the 1992 California motorcycle helmet use law. Am J Public Health. 1995;85:96-9.

27. Olsen CS, Thomas AM, Singleton M, et al. Motorcycle helmet effectiveness in reducing head, face and brain injuries by state and helmet law. Inj Epidemiol. 2016;3. https://doi.org/10.1186/s40621-016-0072-9.

28. Gururaj G. Bangalore Road safety and injury prevention collaborators. Bangalore road safety and injury prevention program: Results and learning, 2007-2010. Bangalore: National Institute of Mental Health and Neuro Sciences; 2011.

29. Fong MC, Measelle JR, Dwyer JL, et al. Rates of motorcycle helmet use and reasons for non-use among adults and children in Luang Prabang, Lao People's Democratic Republic. BMC Public Health. 2015;15:970. https://doi. org/10.1186/s12889-015-2304-2.

30. 'Less than $50 \%$ of riders wear helmet properly' | Delhi News - Times of India. Times India. https://timesofindia.indiatimes.com/city/delhi/less-than-50-ofriders-wear-helmet-properly/articleshow/63260869.cms (Accessed 2 Aug 2020).

31. Thombre A, Ghosh I, Agarwal A. Examining Road Safety Compliance among Motorised TwoWheelers in Delhi- A Cross-Sectional Study. In: Second ASCE India Conference on "Challenges of Resilient and Sustainable Infrastructure Development in Emerging Economies" (CRSIDE2020). Kolkata: 2nd American Society of Civil Engineers (ASCE); 2020.

32. Gururaj G. Head Injuries \& Helmets: helmet legislation and enforcement in Karnataka and India. Bengaluru: National Institute of Mental Health \& Neuro Sciences; 2005.

33. Faryabi J, Rajabi M, Alirezaee S. Evaluation of the use and reasons for not using a helmet by motorcyclists admitted to the emergency ward of Shahid Bahonar Hospital in Kerman. Arch Trauma Res. 2014;3. https://doi.org/10. 5812/atr.19122.

34. Rowden P, Watson B. Motorcycle rider training and perceptions of skill. In: Australasian Road Safety Research, Policing and Education Conference. Adelaide, South Australia; 2008. p. 6. https://acrs.org.au/files/arsrpe/ RS080062.pdf. Accessed 24 Apr 2020.

35. Sreedharan J, Muttappillymyalil J, Divakaran B, et al. Determinants of safety helmet use among motorcyclists in Kerala, India. J Inj Violence Res. 2010;2: 49-54. https://doi.org/10.5249/jivr.v2i1.26.

36. Swaroop M, Marie Siddiqui S, Sagar S, et al. The problem of the pillion rider: India's helmet law and New Delhi's exemption. J Surg Res. 2014;188:64-8. https://doi.org/10.1016/j.jss.2014.01.003.
37. Cordellieri P, Baralla F, Ferlazzo F, et al. Gender effects in young road users on road safety attitudes, behaviors and risk perception. Front Psychol. 2016; 7. https://doi.org/10.3389/fpsyg.2016.01412.

38. Kaliwal MB, Kumar A, Shanbhag AB, et al. Spatio-temporal variations in adult density, abdominal status \& indoor resting pattern of Culex quinquefasciatus Say in Panaji, Goa, India. Indian J Med Res. 2010;9.

39. The Motor Vehicles (Amendment) Act, 2019. Ministry of law and justice (legislative department). Gazette of India. 2019. http://egazette.nic.in/ WriteReadData/2019/210413.pdf. (Accessed 3 Apr 2020).

\section{Publisher's Note}

Springer Nature remains neutral with regard to jurisdictional claims in published maps and institutional affiliations.
Ready to submit your research? Choose BMC and benefit from:

- fast, convenient online submission

- thorough peer review by experienced researchers in your field

- rapid publication on acceptance

- support for research data, including large and complex data types

- gold Open Access which fosters wider collaboration and increased citations

- maximum visibility for your research: over $100 \mathrm{M}$ website views per year

At BMC, research is always in progress.

Learn more biomedcentral.com/submissions 